\title{
Marine microalgae growth and carbon partitioning as a function of nutrient availability
}

\author{
Tomásia Fernandes $^{\mathrm{a}, 1}$, Igor Fernandes ${ }^{\mathrm{a}, 1}$, Carlos A.P. Andrade ${ }^{\mathrm{b}, \mathrm{c}}$, Nereida Cordeiro ${ }^{\mathrm{a}, *}$ \\ ${ }^{a}$ University of Madeira, Faculty of Sciences and Engineering, 9000-390 Funchal, Madeira, Portugal \\ ${ }^{\mathrm{b}}$ Mariculture Center of Calheta, Vila da Calheta, 9370-133 Calheta, Madeira, Portugal \\ c CIIMAR, Interdisciplinary Centre of Marine and Environmental Research, Rua dos Bragas 289, 4050-123 Porto, Portugal
}

\section{H I G H L I G H T S}

- Different growth patterns were attained by microalgae throughout the experiment.

- The intracellular stoichiometry was affected by nutrients availability.

- In $N$. gaditana, the experiment triggered changes in lipid fractions proportions.

- Carbon allocation was channeled towards protein at lowest carbon availabilities.

- Carbohydrate was the main storage pool at high carbon availabilities.

\section{A R T I C L E I N F O}

Article history:

Received 24 February 2016

Received in revised form 23 April 2016

Accepted 3 May 2016

Available online 6 May 2016

\section{Keywords:}

Nutrient availability

Carbon partitioning

N. gaditana

R. marina

Isochrysis $\mathrm{sp}$.
G R A P H I C A L A B S T R A C T

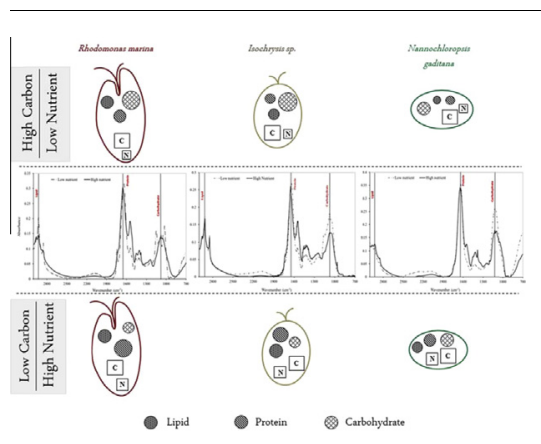

\begin{abstract}
A B S T R A C T
To understand in which way the structural differences of three marine microalgae (Nannochloropsis gaditana, Rhodomonas marina and Isochrysis sp.) affect their carbon partitioning, growth and applicability; a stoichiometric imbalance was imposed by steady carbon and other nutrients variation. Towards high nutrients concentrations/low carbon availability a decrease of $12-51 \%$ in $\mathrm{C} / \mathrm{N}$ microalgae ratio was observed and maximum cell densities were achieved. Moreover, linear correlation between the nutrient input and microalgae protein content were observed. The macromolecular ratios pointed that carbohydrate was the main contributor for the $\mathrm{C} / \mathrm{N}$ decrement. Although lipid content in $R$. marina remained constant throughout the experiment, a rise of $37-107 \%$ in $N$. gaditana and Isochrysis sp. was verified. Lipid fractions revealed high percentages of glycolipids in all microalgae (57-73\% of total lipids). The present study shows an easy way to understand and modulate microalgae carbon partitioning relying on the field of application.
\end{abstract}

(c) 2016 Elsevier Ltd. All rights reserved.

\section{Introduction}

In aquaculture several species of microalgae are used for zooplankton enrichment in bioactive compounds (like proteins

\footnotetext{
* Corresponding author.

E-mail address: ncordeiro@uma.pt (N. Cordeiro).

1 Tomásia Fernandes and Igor Fernandes equally contributed to this work.
}

and neutral lipids) for feeding fish (Zmora et al., 2013). The selection of microalgae strains for aquaculture is based on parameters such as size, digestibility (e.g. cell wall), non-toxicity and nutritional value (Camacho-Rodríguez et al., 2013; Zmora et al., 2013). Meeting these criteria Nannochloropsis sp., Rhodomonas sp. and Isochrysis sp. are cultured as feed for farmed organisms such as bivalves, crab larvae and zooplankton that is then fed for crustacean and fish larvae (Brown, 2002; Camacho-Rodríguez et al., 2013; Zmora et al., 2013). 
Microalgae palatability is related with their gross biochemical composition (lipid, protein and carbohydrate) as with their aggregate energetic value, which, in turn, is dependent on factors such as microalgae phylogeny and variations in their environment conditions which may affect carbon allocation (Palmucci et al., 2011; Pernet et al., 2003; Ratha et al., 2013). Furthermore, the quantity of essential molecules, like polyunsaturated fatty acids, vitamins and sterols, as well as microalgae intracellular stoichiometry may also affect microalgae palatability and biomass applicability (Fidalgo et al., 1998; Palmucci et al., 2011). In order to modulate the latest factors, several strategies have been taken for enhancing the quality of these primary producers to feed aquatic organisms and/or for energy production (Fidalgo et al., 1998; Kim et al., 2014). The manipulation of biotic and abiotic factors related with algae culture conditions, for example temperature, nutrient availability and salinity, can induce changes in growth and biochemical composition of microalgae (Ratha et al., 2013; Xin et al., 2010). The response to changes at different environmental conditions is species-specific (Pernet et al., 2003).

Through photosynthesis microalgae can convert atmospheric $\mathrm{CO}_{2}$ along with water and light into organic matter being carbohydrates the major products (Chen et al., 2013). The excess of fixed carbon is commonly allocated into carbohydrates and lipids, the latter more energy-demanding, and in stressful conditions, like nutritional imbalance, these molecular pools may be used as alternative energy sources for the production of raw materials required by cells (Chen et al., 2013; Chia et al., 2015; Palmucci et al., 2011). In addition, protein can function as nitrogen storage, in some organisms, and changes in this biochemical parameter can reflect the metabolic rate of actively growing/dividing cells (Andersen, 2013; Chen and Vaidyanathan, 2013). The biochemical assessment of microalgae, submitted to environment oscillations, may provide some insights about the structural modifications or molecular mechanisms that can lead to a successful adaptation (Chen and Vaidyanathan, 2013; Chia et al., 2015).

The configuration of core metabolic networks is highly varied across distinct algae classes (Hildebrand et al., 2013). This diversity along with organizational differences in the photosynthetic apparatus might affect processes such as nutrient acquisition and assimilation, carbon allocation and hence the response of microalgae to changes in their environment (Hildebrand et al., 2013). In order to contribute to the knowledge of the effect of carbon availability, the present study evaluated the impact of nutrients stoichiometry on the growth and carbon partitioning in three marine microalgae (Nannochloropsis gaditana, Rhodomonas marina and Isochrysis $\mathrm{sp}$.$) .$

\section{Materials and methods}

\subsection{Chemicals}

All the reagents used for analytical procedures had analytical grade.

\subsection{Microorganisms and culture conditions}

Microalgae strains of Isochrysis sp., R. marina and N. gaditana were supplied by Mariculture Center of Calheta (Madeira Island, Portugal). The cultivation of each microalga was performed by inoculating starter cultures into $500 \mathrm{~mL}$ of enriched seawater. The inoculation cell number was maintained at $2.6 \times 10^{6}$ cells $\mathrm{mL}^{-1}$, for Isochrysis sp. and $N$. gaditana, and $1.4 \times 10^{5}$ cells $\mathrm{mL}^{-1}$, for $R$. marina. The natural seawater used, for media preparation, was previously adjusted to a salinity of $25 \mathrm{~g} \mathrm{~L}^{-1}$ and sterilized in an autoclave (Uniclav 88) at $121^{\circ} \mathrm{C}$ for $15 \mathrm{~min}$. Five
Table 1

Components of the growth medium culture and respective concentrations used in the final growth media $\left(\mathrm{mg} \mathrm{L}^{-1}\right)$.

\begin{tabular}{llllll}
\hline \multirow{2}{*}{ Component } & \multicolumn{5}{l}{ Concentration in final growth medium $\left(\mathrm{mg} \mathrm{L}^{-1}\right)$} \\
\cline { 2 - 6 } & $\mathrm{T} 1$ & $\mathrm{~T} 2$ & $\mathrm{~T} 3$ & $\mathrm{~T} 4$ & $\mathrm{~T} 5$ \\
\hline $\mathrm{NaNO}_{3}$ & 43 & 85 & 170 & 340 & 680 \\
$\mathrm{KH}_{2} \mathrm{PO}_{4}$ & 3 & 7 & 14 & 27 & 54 \\
$\mathrm{EDTA}$ & 2 & 4 & 8 & 15 & 31 \\
$\mathrm{FeCl}_{3} \cdot 6 \mathrm{H}_{2} \mathrm{O}$ & 1 & 3 & 5 & 11 & 22 \\
$\mathrm{ZnCl}_{2}$ & 0.03 & 0.07 & 0.14 & 0.27 & 0.54 \\
$\mathrm{ZnSO}_{4}$ & 0.07 & 0.14 & 0.29 & 0.57 & 1.15 \\
$\mathrm{MnCl}_{2} \cdot 2 \mathrm{H}_{2} \mathrm{O}$ & 0.04 & 0.08 & 0.16 & 0.32 & 0.65 \\
$\mathrm{Na}_{2} \mathrm{MoO}_{4} \cdot 2 \mathrm{H} \mathrm{O}$ & 0.01 & 0.01 & 0.02 & 0.05 & 0.10 \\
$\mathrm{CoCl}_{2} \cdot 6 \mathrm{H} 2 \mathrm{O}$ & 0.01 & 0.01 & 0.02 & 0.05 & 0.10 \\
$\mathrm{CuSO}_{4} \cdot 5 \mathrm{H}_{2} \mathrm{O}$ & 0.01 & 0.01 & 0.03 & 0.05 & 0.10 \\
$\mathrm{MgSO}_{4} \cdot 7 \mathrm{H}_{2} \mathrm{O}$ & 0.12 & 0.25 & 0.49 & 0.98 & 1.97 \\
$\mathrm{Vitamins}$ & & & & & \\
$\mathrm{Thiamine}_{\text {Biotin }}$ & 0.01 & 0.02 & 0.04 & 0.07 & 0.14 \\
$\mathrm{~B}_{12}$ & 0.001 & 0.003 & 0.005 & 0.010 & 0.020 \\
\hline
\end{tabular}

different volumes of nutrient solution Nutribloom Plus (Necton, Portugal), 250 (T1), 500 (T2), 1000 (T3), 2000 (T4) and 4000 (T5) $\mu \mathrm{L} \mathrm{L}^{-1}$, were used for the preparation of the growth medium. The nutrient concentrations in the final growth medium are presented in Table 1.

Experiments were conducted at a temperature of $23 \pm 2{ }^{\circ} \mathrm{C}$, with a photoperiod of 18:6 h light/dark cycles, $\mathrm{pH} 8 \pm 1$, at a light intensity of $52 \mu \mathrm{mol} \mathrm{m}{ }^{-2} \mathrm{~s}^{-1}$ and compressed air $\left(125 \mathrm{~mL} \mathrm{~min}^{-1}\right)$ was used for aeration of cell cultures and as the only carbon source. The microalgae were harvested at stationary phase by centrifugation (centrifuge Labofuge 200 - Heraeus) for $5 \mathrm{~min}$ at $4500 \mathrm{rpm}$ and washed with distilled water.

\subsection{Cell concentration and specific growth rate determination}

Microalgae growth was monitored daily by counting cells with a $0.1 \mathrm{~mm}$ deep improved Neubauer haemocytometer (Marienfeld - Superior) and a light microscope (Olympus BX41) using a 40x magnification. For cell counting, cells were fixed with lugol. A logistic model was used to describe algal growth, as previously presented by Xin et al. (2010), Eq. (1):

$\mathrm{N}=\frac{K}{1+e^{a-r t}}$

where $K$ (cells $\mathrm{mL}^{-1}$ ) is the carrying capacity, $N$ (cells $\mathrm{mL}^{-1}$ ) is the cell concentration in time $t$ (days), $a$ is a constant that refers to the position of the origin and $r\left(\mathrm{~d}^{-1}\right)$ is the specific growth rate. The specific growth rate was calculated by the linearization of the logistic model.

\subsection{Analytical procedures}

For the determination of CHNS content in all experiments an elemental analyser Truspec 630 - 200 - 200 was used. Total protein was assessed by multiplying the nitrogen content for 6.25 as described by Kim et al. (2014). Fourier transform infrared spectroscopy (FT-IR) was used in order to perform the carbohydrate: lipid and carbohydrate: protein ratio analysis as previously reported by Montechiaro et al. (2006). FT-IR spectra were collected on a Perkin-Elmer Spectrum Two instrument and band assignments were made according to Dean et al. (2010), Giordano et al. (2001) and Montechiaro et al. (2006).

Extraction of total lipids was performed according to modified Bligh and Dyer (1959). Briefly, to dried algal biomass was added $3 \mathrm{~mL}$ of a methanol: chloroform mixture $(2: 1 \mathrm{v} / \mathrm{v})$ followed by 
$400 \mu \mathrm{L}$ of a saturated solution of $\mathrm{KCl}$ and $2 \mathrm{~mL}$ of chloroform. After homogenization, $2 \mathrm{~mL}$ of distilled water were added and the mixture was left stirring for $15 \mathrm{~min}$. Then, the sample was let to set and the organic phase was removed and dried in $\mathrm{Na}_{2} \mathrm{SO}_{4}$ filters. At the end, solvent was evaporated in a Büchi rotavapor R-200, in order to proceed to lipids quantification. Lipid content was quantified gravimetrically. Lipids and protein contents are presented relatively to dry biomass weight (DW) as average of at least two replicates.

For lipid class determination the total lipids were solubilized in dichloromethane and fractionated in activated silica $\left(100^{\circ} \mathrm{C}\right)$ chromatography column. The separation of lipid classes was made according to Guckert et al. (1985) and Smith et al. (1986), procedures being the elution sequence as follows: $5 \mathrm{~mL}$ of dichloromethane, $5 \mathrm{~mL}$ of acetone, and finally, $10 \mathrm{~mL}$ of methanol. These elutions allow the separation of the different lipid fractions: neutral lipids, phospholipids and polar lipids (glycolipids).

\subsection{Statistical analysis}

Values are represented as means \pm standard deviations of at least two replicates. In algal growth curves non-linear regression trend lines where fit to data with Solver. Statistical analysis of the data was carried out using the software IBM SPSS Statistics 23. Differences between growth medium nutrient availability treatments were assessed by one-way analysis of variance (ANOVA) followed by a Bonferroni's Post Hoc analysis; $p$ values $<0.05$ were considered to be statistically significant.

\section{Results and discussion}

\subsection{Algal growth}

The different growth patterns (Fig. 1) reflected the impact of the five nutrient regimes in the microalgae studied. Therefore, is possible to note that maximum cells concentration were attained by microalgae in $\mathrm{T} 4$ growth medium (Fig. $1 \mathrm{a}-\mathrm{c}$ ) and that maximum cells concentration decreased in $\mathrm{T} 5$ for both $N$. gaditana and $R$. marina, $21 \%$ and $28 \%$, respectively. Treatments T4 and T5 presented the highest nutrients concentration (Lee et al., 2015). Thus, the decrement observed in $\mathrm{T} 5$ might be because at this stage light becomes limiting or the nutrients concentration is such that may be harmful and lead to reduced cells concentration in these microalgae (Grobbelaar, 2013; Lee et al., 2015).

At lower nutrient inputs (T1-T3) the highest specific growth rates $\left(0.90-0.81 \mathrm{~d}^{-1}\right)$ were achieved for $N$. gaditana as well as for $R$. marina $\left(1.22-1.56 \mathrm{~d}^{-1}\right)$. In the present study, carbon was kept constant and overall nutrients concentration was modified. This lead to a stoichiometric imbalance, where the ratio of the carbon with the nutrients in the growth medium was higher in treatments with decreased nutrient availability in growth media (T1-T3). Thus, $N$. gaditana and $R$. marina growth rate was influenced by nutrient availability and/or stoichiometric imbalance of carbon with the other elements in growth medium.

Isochrysis sp. revealed a different trend regarding to the specific growth rate, as the maximum values attained $\left(1.16\right.$ and $\left.1.05 \mathrm{~d}^{-1}\right)$ appeared to have no direct relation with nutrient availability. (a)

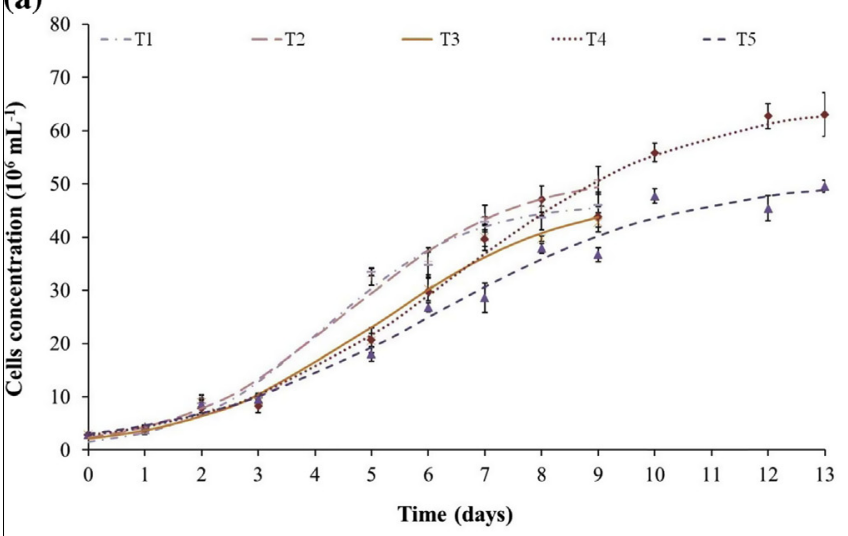

(b)

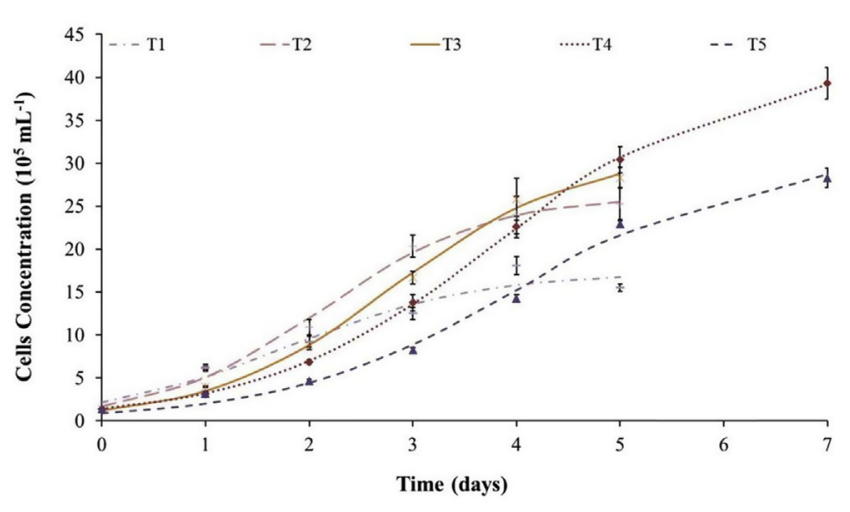

(c)

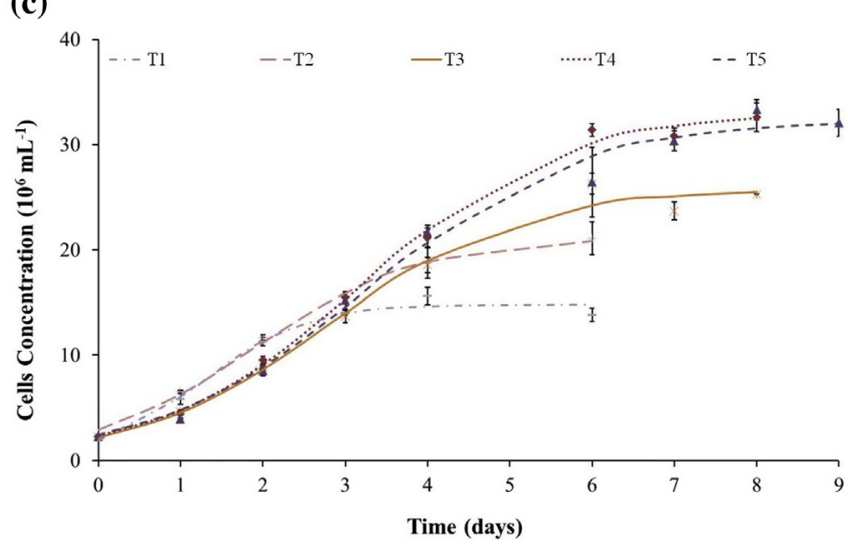

Fig. 1. Growth curves for (a) N. gaditana, (b) R. marina and (c) Isochrysis sp. upon different nutrient availabilities in the growth media. 
Knowing that the correlation between growth and nutrient concentration is influenced by environmental factors and that light intensity is one of the critical requirements (Lee et al., 2015; Stehfest et al., 2005), this result might be due to two reasons: (i) the growth of this microalga specie was saturated at the lowest nutrients concentration; (ii) light intensity was below the saturated light level being the growth limited by it (light-limitation) (Lee et al., 2015).

\subsection{Biochemical composition}

Algal culture medium comprises inorganic salts, macro and micronutrients, which some are rate limiting for algal growth (Karemore et al., 2013). Thus, it is important to assess the impact of nutrient availability over the nutrient uptake and the enhancement of the nutritional quality of these primary producers.

The microalgae $\mathrm{C} / \mathrm{N}$ ratios, presented in Table 2 , indicate that their intracellular stoichiometry was significantly affected by the nutrients availability. In the three marine microalgae studied, the $\mathrm{C} / \mathrm{N}$ ratio was higher in treatments with the lowest nutrient concentrations/high carbon availability (T1 and T2), decreasing 12$51 \%$ as the nutrient availability increased. This behaviour was previously observed for many microalgae strains which in nutrient deficient conditions allocated a larger proportion of carbon into molecular pools depleted of nitrogen (e.g. carbohydrates and lipids) increasing their cells $\mathrm{C} / \mathrm{N}$ ratio (Chen et al., 2013; Fidalgo et al., 1998; Palmucci et al., 2011). Towards high nutrients concentration the decrement in $\mathrm{C} / \mathrm{N}$ ratio may indicate the utilization of the carbon skeletons for the production of nitrogenous pools (e.g. proteins). In nutrient saturation conditions ( $\mathrm{T} 4$ and $\mathrm{T} 5$ ), the $\mathrm{C} / \mathrm{N}$ ratios obtained for $R$. marina and Isochrysis sp. were closer to those referred in Seixas et al. (2009) for another strain of Rhodomonas (4.4) and for Isochrysis galbana (8.8). Regarding N. gaditana, the C/ $\mathrm{N}$ ratios (6.68 and 6.85) achieved in nutrient saturation conditions were closer to the Redfield ratio (6.6) (Seixas et al., 2009).

Nitrogen is an essential component for microalgae growth and is associated with protein biosynthesis (Chen et al., 2013). In nutrient-rich conditions some organisms can assimilate the excess nitrogen in culture medium and store it into protein (Andersen, 2013). In the present work, linear trends were obtained for total protein content, in dry biomass, against nutrient availability for the first four nutrient concentrations assessed (T1-T4), presenting linear correlation coefficients $\left(R^{2}\right)$ between 0.95 and 0.99 . To nourish bivalve larvae, the microalgae species must contain at least $12 \%$ of protein in their composition despite of the optimum range being $30-60 \%$ of protein in dry biomass (Renaud et al., 2002). Thus, for the three microalgae studied, only Isochrysis sp. and R. marina were within the optimum range being the highest values obtained of $36.89 \%$ and $58.85 \%$ of dry weight, respectively (Table 2 ). However, the maximum protein values obtained for $N$. gaditana at T4 and T5 (18.81-19.70\% of dry biomass) also makes it suitable for bivalve diet (Renaud et al., 2002).

The strategies often applied for channel metabolic fluxes towards lipid accumulation are mainly nitrogen and phosphorus starvation or carbon increase (Courchesne et al., 2009; Palmucci et al., 2011). The lipid content of $N$. gaditana and Isochrysis sp. was responsive to the variation of the external nutrient concentrations presenting their lowest lipid contents at low nutrients concentrations (T1 and T2) and increasing this organic pool towards high nutrient concentrations/low carbon availabilities. In opposition, $R$. marina lipid content remained relatively constant in different treatments but declined at the maximum nutrients concentration (T5). According to Courchesne et al. (2009), microalgae under nutrient limitation accumulate lipids when cellular mechanisms for photosynthesis are active and the energy source along with carbon source are abundant and available. In this study, nitrogen and phosphorus concentration varied besides other nutrients like iron and magnesium which are crucial for photosystems photochemistry and may affect photosynthetic energy conversion along with fundamental enzymatic reactions that influence the downstream metabolic reactions (Zhang et al., 2014). Moreover, the microalgae phylogeny and the way in which stoichiometric imbalance is generated may affect the response of microalgae and hence carbon allocation (Palmucci et al., 2011).

\subsection{Lipid class content}

Algal lipids can be divided into two major classes: neutral/nonpolar lipids - that are known as the metabolic energy reserves of the cell, and polar lipids (glycolipids and phospholipids) - that play a structural role as components of biomembranes (Li et al., 2014; Penezić et al., 2010). In algae, environmental stresses can induce fluctuations in the fluidity of cell membranes (Kumari et al., 2013). Although these fluctuations are not fully understood, it is often admitted that they are needed to alter physiological properties of biomembranes in order to maintain normal cell processes, such as ion permeability and photosynthesis (Kumari et al., 2013).

A higher content of polar lipids (glycolipids and phospholipids) was observed over the neutral/non polar lipids, being glycolipids the main fraction in all experiments performed for the three microalgae (Fig. 2). The highest glycolipids percentages of total lipids were $57 \%$ for Isochrysis sp., $73 \%$ for $R$. marina and $61 \%$ for $N$. gaditana. Algae grown under their natural environment often possess large amounts of polar lipids and the glycolipid are predominantly located in photosynthetic membranes, maintaining the stability of photosynthetic apparatus that is crucial for metabolic activities (Bondioli et al., 2012; Kumari et al., 2013).

Table 2

Effect of nutrient availability in the biochemical composition of $N$. gaditana, R. marina and Isochrysis sp.

\begin{tabular}{|c|c|c|c|c|c|c|}
\hline \multirow[t]{2}{*}{ Parameter } & \multirow[t]{2}{*}{ Microalgae } & \multicolumn{5}{|l|}{ Treatments } \\
\hline & & $\mathrm{T} 1$ & $\mathrm{~T} 2$ & T3 & $\mathrm{T} 4$ & T5 \\
\hline \multirow[t]{3}{*}{$\mathrm{C} / \mathrm{N}(\mathrm{mol} / \mathrm{mol})$} & N. gaditana & $13.65 \pm 0.22^{\mathrm{a}}$ & $10.85 \pm 0.14^{b}$ & $8.60 \pm 0.27^{c}$ & $6.68 \pm 0.02^{d}$ & $6.85 \pm 0.08^{d}$ \\
\hline & R. marina & $11.70 \pm 0.22^{\mathrm{a}}$ & $9.73 \pm 0.02^{\mathrm{b}}$ & $5.69 \pm 0.04^{c}$ & $5.34 \pm 0.04^{\mathrm{cd}}$ & $5.18 \pm 0.01^{d}$ \\
\hline & Isochrysis sp. & $14.63 \pm 0.10^{\mathrm{a}}$ & $12.15 \pm 0.38^{\mathrm{b}}$ & $10.68 \pm 0.08^{c}$ & $8.78 \pm 0.36^{\mathrm{d}}$ & $8.79 \pm 0.07^{d}$ \\
\hline \multirow[t]{3}{*}{ Protein (\% DW) } & N. gaditana & $2.82 \pm 0.35^{a}$ & $3.17 \pm 0.18^{a}$ & $8.58 \pm 0.10^{\mathrm{b}}$ & $18.81 \pm 0.05^{\mathrm{c}}$ & $19.70 \pm 0.03^{d}$ \\
\hline & R. marina & $18.69 \pm 0.27^{\mathrm{a}}$ & $26.68 \pm 0.72^{\mathrm{b}}$ & $44.48 \pm 0.31^{\mathrm{c}}$ & $58.85 \pm 0.78^{d}$ & $46.34 \pm 0.38^{c}$ \\
\hline & Isochrysis sp. & $12.12 \pm 0.46^{\mathrm{a}}$ & $13.85 \pm 1.13^{a}$ & $25.09 \pm 0.52^{\mathrm{b}}$ & $36.89 \pm 1.51^{\mathrm{c}}$ & $36.35 \pm 0.38^{c}$ \\
\hline \multirow[t]{3}{*}{ Lipid (\% DW) } & $N$. gaditana & $1.88 \pm 0.01^{\mathrm{a}}$ & $1.54 \pm 0.02^{\mathrm{a}}$ & $3.18 \pm 0.16^{b}$ & $4.94 \pm 0.22^{c}$ & $5.15 \pm 0.04^{c}$ \\
\hline & R. marina & $19.04 \pm 0.33^{a}$ & $20.54 \pm 0.26^{a}$ & $18.92 \pm 0.10^{\mathrm{a}}$ & $20.24 \pm 0.56^{\mathrm{a}}$ & $15.75 \pm 1.48^{\mathrm{b}}$ \\
\hline & Isochrysis sp. & $16.80 \pm 1.31^{\mathrm{a}}$ & $14.72 \pm 1.29^{\mathrm{a}}$ & $23.01 \pm 1.58^{\mathrm{b}}$ & $24.83 \pm 2.05^{b}$ & $25.52 \pm 0.32^{b}$ \\
\hline
\end{tabular}

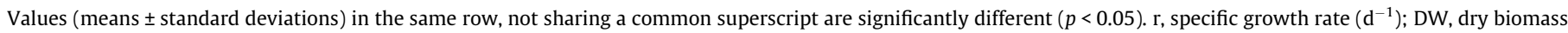
weight. 
(a)

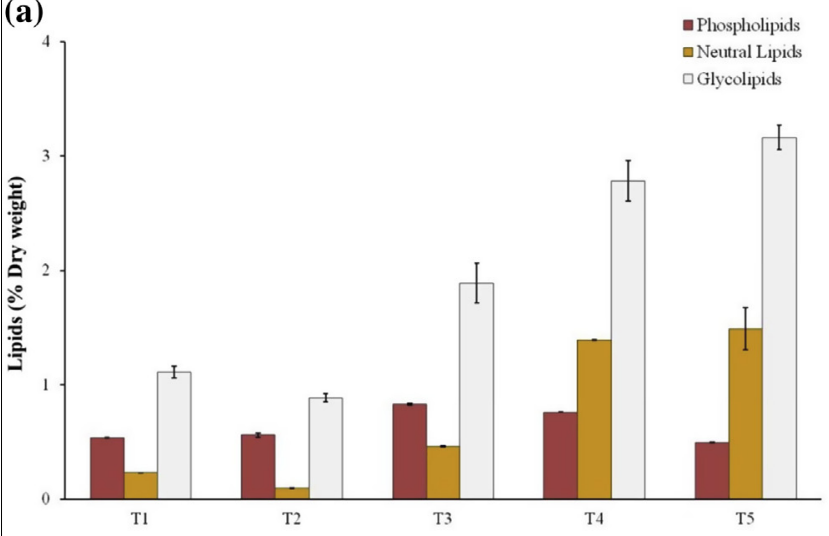

(b)

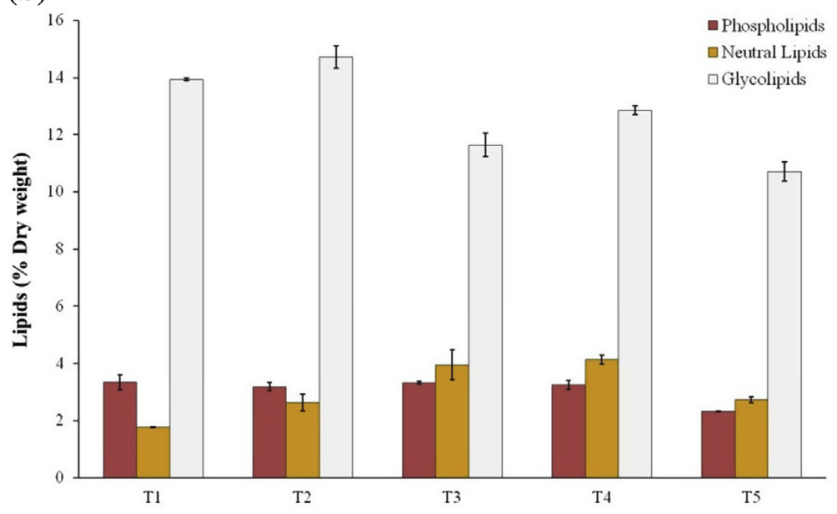

(c)

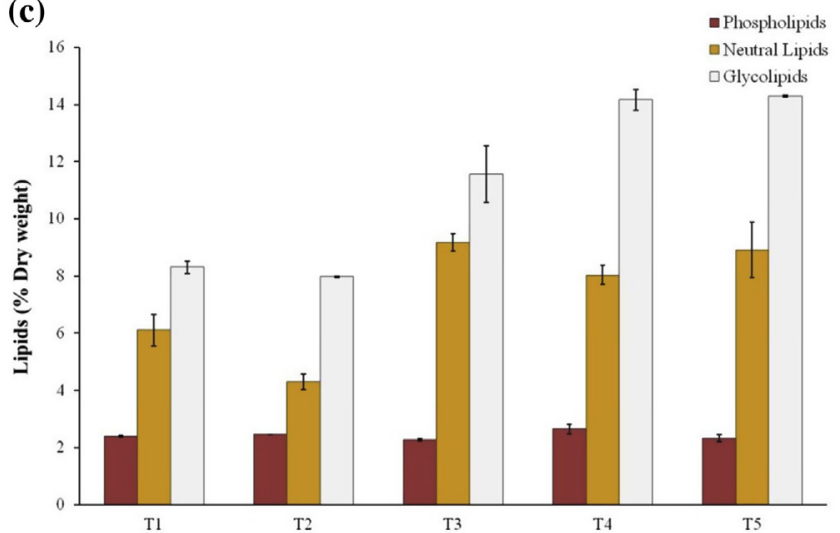

Fig. 2. Lipid class content of (a) N. gaditana, (b) R. marina and (c) Isochrysis sp. in different nutrients availability in the growth media.

Along with total lipids of the microalgae, lipid class (neutral and polar lipids) content varied in function of nutrients availability (Fig. 2). In N. gaditana (Fig. 2a), changes in the lipid fractions proportions showed a mobilization of phospholipid to neutral lipids as nutrients concentration increased. Moreover, the highest phospholipid content (29\% and $36 \%$ of total lipid) was obtained at the lowest growth medium nutrient availabilities (T1 and T2) by this microalga. High salt and iron content are known to result in neutral lipid enhancement (De Bhowmick et al., 2015). In this experiment, treatments with high nutrients input, iron included, may have resulted in high salinity content explaining the accumulation of lipid in both Isochrysis sp. and N. gaditana. Moreover the trend previously observed in $N$. gaditana suggest that treatments triggered the synthesis pathway of lipid from polar lipid to neutral (He et al., 2015). Phospholipid content in R. marina (Fig. 2b) and Isochrysis sp. (Fig. 2c) were within the values previously reported by Kumari et al. (2013) as common for algae, approximately 10$20 \%$ of total lipids.

\subsection{Carbohydrate/lipid and carbohydrate/amide ratios}

Microalgae biomass may be suitable for biodiesel production if rich in neutral lipids whereas rich in carbohydrates it can be converted to produce bioethanol (Chen et al., 2013). The results showed a decrease in $\mathrm{C} / \mathrm{N}$ microalgae ratio alongside with an increment in protein and lipid content of the algae. In order to evaluate whether the microalgae accumulate lipids towards high nutrient availabilities and carbohydrates at low nutrient availabilities, the relative carbohydrate abundance was determined (Table 3 ) by cal- culating the ratios of the carbohydrate bands $\left(1200-1020 \mathrm{~cm}^{-1}\right)$ to the amide $\mathrm{I}\left(\sim 1655 \mathrm{~cm}^{-1}\right)$ and lipid $\left(\sim 2950 \mathrm{~cm}^{-1}\right)$ bands (Dean et al., 2010).

FT-IR spectra of algal samples from treatments T1, T3 and T5 show that the applied treatments enhanced a change in the macromolecular pools (see Supplementary Data Fig. 1). For Isochrysis sp. and $N$. gaditana the carbohydrate/lipid (C/L) ratio decreased with the rise of nutrient input being the lowest value achieved at T5. This suggests that the increase of nutrient availability, in these microalgae, induces lipids accumulation and that carbohydrate is their major carbon sink under low nutrient availability conditions. Results for Isochrysis sp. confirm Wang et al. (2014) assumptions that carbohydrate is the major carbon sink in the genus Isochrysis under stressful conditions. In $R$. marina the maximum $\mathrm{C} / \mathrm{L}$ ratio was attained in T1 (0.83) and T5 (0.95) displaying a different trend for this microalgae species.

In the FT-IR spectra of $N$. gaditana, R. marina and Isochrysis sp., is possible to observe a distinct absorption band at $\sim 1655 \mathrm{~cm}^{-1}$ attributed to $\mathrm{C}=\mathrm{O}$ stretching of amides from proteins (see Supplementary Data Fig. 1a-c) (Dean et al., 2010). All three microalgae presented carbohydrate/amide $(\mathrm{C} / \mathrm{P})$ ratios lower than one denoting that proteins were in higher amounts than carbohydrates. Moreover, the analytical result trends for these two macromolecular pools were similar to that aforementioned for carbohydrates and lipids.

In summary, there appears to be three probable strategies, with respect to carbon allocation, taken by the microalgae studied towards high nutrients concentrations: (i) carbohydrate changed as well as lipid and protein content; (ii) carbohydrate remained 
Table 3

Effect of nutrient availability on carbohydrate: lipid (C/L) and carbohydrate: protein (C/P) ratio of N. gaditana, R. marina and Isochrysis sp.

\begin{tabular}{|c|c|c|c|c|c|c|}
\hline \multirow[t]{2}{*}{ Ratios } & \multirow[t]{2}{*}{ Microalgae } & \multicolumn{5}{|l|}{ Treatments } \\
\hline & & $\mathrm{T} 1$ & $\mathrm{~T} 2$ & T3 & $\mathrm{T} 4$ & T5 \\
\hline \multirow[t]{3}{*}{$\mathrm{C}\left(1200-1020 \mathrm{~cm}^{-1}\right) / \mathrm{L}\left(\sim 2950 \mathrm{~cm}^{-1}\right)$} & N. gaditana & $2.41 \pm 0.01^{\mathrm{a}}$ & $3.68 \pm 0.29^{b}$ & $1.85 \pm 0.02^{\text {ce }}$ & $1.24 \pm 0.05^{\mathrm{de}}$ & $1.43 \pm 0.02^{\mathrm{e}}$ \\
\hline & R. marina & $0.83 \pm 0.06^{\mathrm{a}}$ & $0.81 \pm 0.04^{\mathrm{ab}}$ & $0.60 \pm 0.01^{\mathrm{c}}$ & $0.72 \pm 0.03^{\mathrm{abc}}$ & $0.95 \pm 0.01^{\mathrm{d}}$ \\
\hline & Isochrysis sp. & $1.31 \pm 0.08^{a}$ & $1.08 \pm 0.00^{\mathrm{b}}$ & $0.88 \pm 0.06^{\mathrm{c}}$ & $0.81 \pm 0.03^{\mathrm{cd}}$ & $0.74 \pm 0.02^{\mathrm{dc}}$ \\
\hline \multirow[t]{3}{*}{$\mathrm{C}\left(1200-1020 \mathrm{~cm}^{-1}\right) / \mathrm{P}\left(\sim 1655 \mathrm{~cm}^{-1}\right)$} & N. gaditana & $0.71 \pm 0.06^{\mathrm{a}}$ & $0.87 \pm 0.02^{\mathrm{ab}}$ & $0.61 \pm 0.05^{\mathrm{ac}}$ & $0.65 \pm 0.01^{\mathrm{acd}}$ & $0.53 \pm 0.05^{c d}$ \\
\hline & R. marina & $0.60 \pm 0.05^{\mathrm{a}}$ & $0.73 \pm 0.01^{\mathrm{b}}$ & $0.25 \pm 0.01^{\mathrm{c}}$ & $0.33 \pm 0.04^{c}$ & $0.46 \pm 0.01^{\mathrm{d}}$ \\
\hline & Isochrysis sp. & $0.71 \pm 0.03^{a}$ & $0.82 \pm 0.01^{\mathrm{ab}}$ & $0.63 \pm 0.01^{\mathrm{ac}}$ & $0.49 \pm 0.03^{d}$ & $0.48 \pm 0.01^{\mathrm{d}}$ \\
\hline
\end{tabular}

Values (means \pm standard deviations) in the same row, not sharing a common superscript are significantly different $(p<0.05)$.

constant whereas lipid and protein content changed; (iii) carbohydrate changed and lipid content remained constant whereas protein increased.

In order to verify which one of the strategies was really taken by microalgae, the carbohydrates determination, by the subtraction of protein, lipid and ashes at $650{ }^{\circ} \mathrm{C}$, was made. Therefore, in N. gaditana it was verified that carbohydrate remained unresponsive to the environment oscillations whereas lipid and protein content increased. In Isochrysis sp. carbohydrates decreased in contrast to lipid and protein content. In $R$. marina carbohydrates decreased with the nutrient input, lipid remained constant and protein content increased.

\section{Conclusions}

The three marine microalgae were responsive to the stoichiometric imbalance generated by the steady carbon. The growth patterns reflected the induced variations in the external medium. In high carbon availability, microalgae increased their intracellular composition in carbon rich pools. On the contrary, in low carbon availability/high nutrients concentration, microalgae displaced their carbon fluxes to protein accumulation. The response of lipid and carbohydrate pools might be dependent on microalgae specie, which may affect their energetic value and hence their palatability. The accumulation of carbohydrates observed in Isochrysis sp. and $R$. marina at low nutrient concentrations might be interesting to bioethanol production.

\section{Acknowledgements}

This study was partially supported by the Oceanic Observatory of Madeira (M1420-01-0145-FEDER-000001-Observatório Oceânico da Madeira-OOM).

\section{Appendix A. Supplementary data}

Supplementary data associated with this article can be found, in the online version, at http://dx.doi.org/10.1016/j.biortech.2016.05. 001.

\section{References}

Andersen, R.A., 2013. The microalgal cell. In: Richmond, A., Hu, Q. (Eds.), Handbook of Microalgal Culture: Applied Phycology and Biotechnology. John Wiley \& Sons, New York, pp. 3-20.

Bligh, E.G., Dyer, W.J., 1959. A rapid method of total lipid extraction and purification. Can. J. Biochem. Phys. 37, 911-917.

Bondioli, P., Della Bella, L., Rivolta, G., Chini Zittelli, G., Bassi, N., Rodolfi, L., Casini, D., Prussi, M., Chiaramonti, D., Tredici, M.R., 2012. Oil production by the marine microalgae Nannochloropsis sp. F\&M-M24 and Tetraselmis suecica F\&M-M33. Bioresour. Technol. 114, 567-572.

Brown, M.R., 2002. Nutritional value and use of microalgae in aquaculture. In: CruzSuárez, L.E., Ricque-Marie, D., Tapia-Salazar, M., Gaxiola-Cortés, M.G., Simoes, N. (Eds.), Avances en Nutrición Acuícola VI, Memorias del VI Simposium Internacional de Nutrición Acuícola, Cancún, Quintana Roo, México.
Camacho-Rodríguez, J., Cerón-García, M.C., González-López, C.V., Fernández-Sevilla, J.M., Contreras-Gómez, A., Molina-Grima, E., 2013. A low-cost culture medium for the production of Nannochloropsis gaditana biomass optimized for aquaculture. Bioresour. Technol. 144, 57-66.

Chen, Y., Vaidyanathan, S., 2013. Simultaneous assay of pigments, carbohydrates, proteins and lipids in microalgae. Anal. Chim. Acta 776, 31-40.

Chen, C.-Y., Zhao, X.-Q., Yen, H.-W., Ho, S.-H., Cheng, C.-L., Lee, D.-J., Bai, F.-W., Chang, J.-S., 2013. Microalgae-based carbohydrates for biofuel production. Biochem. Eng. J. 78, 1-10.

Chia, M.A., Lombardi, A.T., Melao, M.G.G., Parrish, C.C., 2015. Combined nitrogen limitation and cadmium stress stimulate total carbohydrates, lipids, protein and amino acid accumulation in Chlorella vulgaris (Trebouxiophyceae). Aquat. Toxicol. 160, 87-95.

Courchesne, N.M., Parisien, A., Wang, B., Lan, C.Q., 2009. Enhancement of lipid production using biochemical, genetic and transcription factor engineering approaches. J. Biotechnol. 141, 31-41.

De Bhowmick, G., Koduru, L., Sen, R., 2015. Metabolic pathway engineering towards enhancing microalgal lipid biosynthesis for biofuel application - a review Renewable Sustainable Energy Rev. 50, 1239-1253.

Dean, A.P., Sigee, D.C., Estrada, B., Pittman, J.K., 2010. Using FTIR spectroscopy for rapid determination of lipid accumulation in response to nitrogen limitation in freshwater microalgae. Bioresour. Technol. 101, 4499-4507.

Fidalgo, J.P., Cid, A., Torres, E., Sukenik, A., Herrero, C., 1998. Effects of nitrogen source and growth phase on proximate biochemical composition, lipid classes and fatty acid profile of the marine microalga Isochrysis galbana. Aquaculture 166, 105-116.

Giordano, M., Kansiz, M., Heraud, P., Beardall, J., Wood, B., McNaughton, D., 2001 Fourier transform infrared spectroscopy as a novel tool to investigate changes in intracellular macromolecular pools in the marine microalga Chaetoceros muelleri (Bacillariophyceae). J. Phycol. 37, 271-279.

Grobbelaar, J.U., 2013. Inorganic algal nutrition. In: Richmond, A., Hu, Q. (Eds.), Handbook of Microalgal Culture: Applied Phycology and Biotechnology. John Wiley \& Sons, New York, pp. 123-133.

Guckert, J.B., Antworth, C.P., Nichols, P.D., White, D.C., 1985. Phospholipid, esterlinked fatty acid profiles as reproducible assays for changes in prokaryotic community structure of estuarine sediments. Microb. Ecol. 31, 147-158.

He, Q., Yang, H., Wu, L., Hu, C., 2015. Effect of light intensity on physiological changes, carbon allocation and neutral lipid accumulation in oleaginous microalgae. Bioresour. Technol. 191, 219-228.

Hildebrand, M., Abbriano, R.M., Polle, J.E., Traller, J.C., Trentacoste, E.M., Smith, S.R., Davis, A.K., 2013. Metabolic and cellular organization in evolutionarily diverse microalgae as related to biofuels production. Curr. Opin. Chem. Biol. 17, 506514.

Karemore, A., Pal, R., Sen, R., 2013. Strategic enhancement of algal biomass and lipid in Chlorococcum infusionum as bioenergy feedstock. Algal Res. 2, 113-121.

Kim, C.W., Sung, M.G., Nam, K., Moon, M., Kwon, J.H., Yang, J.W., 2014. Effect of monochromatic illumination on lipid accumulation of Nannochloropsis gaditana under continuous cultivation. Bioresour. Technol. 159, 30-35.

Kumari, P., Kumar, M., Reddy, C.R.K., Jha, B., 2013. Algal lipids, fatty acids and sterols. Woodhead Publishing Limited, pp. 87-144.

Lee, E., Jalalizadeh, M., Zhang, Q., 2015. Growth kinetic models for microalgae cultivation: a review. Algal Res. 12, 497-512.

Li, Y., Naghdi, F.G., Garg, S., Adarme-Vega, T.C., Thurecht, K.J., Ghafor, W.A., Tannock, S., Schenk, P.M., 2014. A comparative study: the impact of different lipid extraction methods on current microalgal lipid research. Microb. Cell Fact. 13, $1-9$.

Montechiaro, F., Hirschmugl, C.J., Raven, J.A., Giordano, M., 2006. Homeostasis of cell composition during prolonged darkness. Plant Cell Environ. 29, 2198-2204.

Palmucci, M., Ratti, S., Giordano, M., 2011. Ecological and evolutionary implications of carbon allocation in marine phytoplankton as a function of nitrogen availability: a fourier transform infrared spectroscopy approach (1). J. Phycol. 47, 313-323.

Penezić, A., Gašparović, B., Burić, Z., Frka, S., 2010. Distribution of marine lipid classes in salty Rogoznica Lake (Croatia). Estuarine Coastal Mar. Sci. 86, 625636.

Pernet, F., Tremblay, R., Demers, E., Roussy, M., 2003. Variation of lipid class and fatty acid composition of Chaetoceros muelleri and Isochrysis sp. grown in a semicontinuous system. Aquaculture 221, 393-406. 
Ratha, S.K., Prasanna, R., Prasad, R.B.N., Sarika, C., Dhar, D.W., Saxena, A.K., 2013. Modulating lipid accumulation and composition in microalgae by biphasic nitrogen supplementation. Aquaculture 392-395, 69-76.

Renaud, S.M., Thinh, L.-V., Lambrinidis, G., Parry, D.L., 2002. Effect of temperature on growth, chemical composition and fatty acid composition of tropica Australian microalgae grown in batch cultures. Aquaculture 211, 195214.

Seixas, P., Coutinho, P., Ferreira, M., Otero, A., 2009. Nutritional value of the cryptophyte Rhodomonas lens for Artemia sp. J. Exp. Mar. Biol. Ecol. 381, 1-9.

Smith, G.A., Nichols, P.D., White, D.C., 1986. Fatty acid composition and microbia activity of benthic marine sediment from McMurdo sound, Antarctica. Microbiol. Ecol. 38, 219-231.

Stehfest, K., Toepel, J., Wilhelm, C., 2005. The application of micro-FTIR spectroscopy to analyze nutrient stress-related changes in biomass composition of phytoplankton algae. Plant Physiol. Biochem. 43, 717-726.
Wang, H.T., Yao, C.H., Ai, J.N., Cao, X.P., Xue, S., Wang, W.L., 2014. Identification of carbohydrates as the major carbon sink of the marine microalga Isochrysis zhangjiangensis (Haptophyta) and optimization of its productivity by nitrogen manipulation. Bioresour. Technol. 171, 298-304.

Xin, L, Hu, H.Y, Ke, G, Sun, YX, 2010. Effects of different nitrogen and phosphorus concentrations on the growth, nutrient uptake, and lipid accumulation of a freshwater microalga Scenedesmus sp. Bioresour. Technol. 101, 5494-5500.

Zhang, C., Zhang, Y., Zhuang, B., Zhou, X., 2014. Strategic enhancement of alga biomass, nutrient uptake and lipid through statistical optimization of nutrient supplementation in coupling Scenedesmus obliquus-like microalgae cultivation and municipal wastewater treatment. Bioresour. Technol. 171, 71-79.

Zmora, O., Grosse, DJ. Zou, N., Samocha, T.M., 2013. Microalga for aquaculture: practical implications. In: Richmond, A., Hu, Q. (Eds.), Handbook of Microalgal Culture: Applied Phycology and Biotechnology. John Wiley \& Sons, New York, pp. 628-652. 